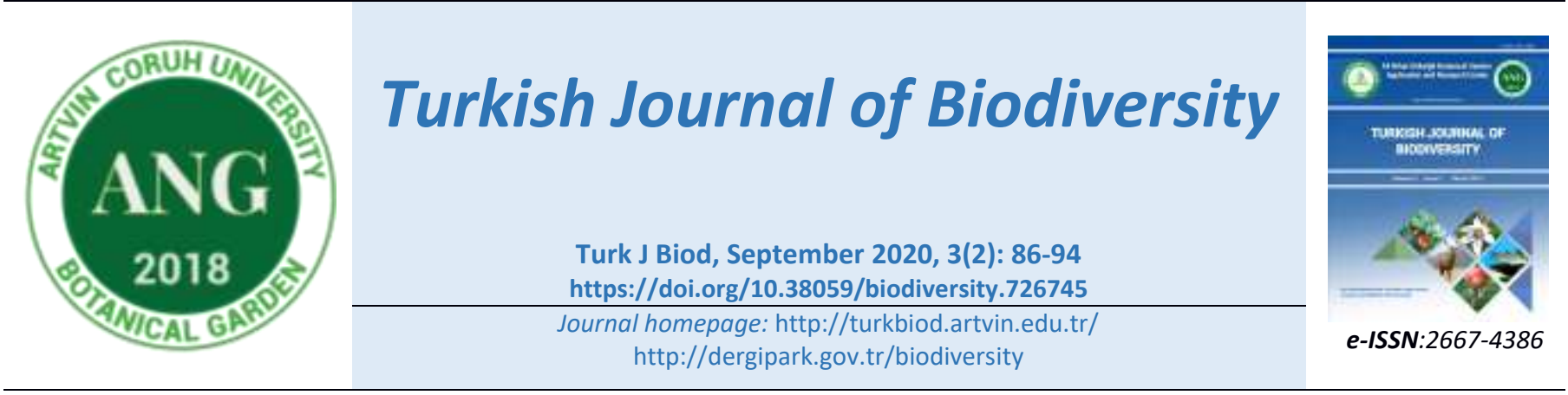

REVIEW ARTICLE

Open Access

\title{
General overview on the conservation of medicinal plants in Turkey
}

\section{Türkiye'de tıbbi bitkilerin korunmasına genel bakış}

\author{
Emine AKALIN $\odot$, Bahar GÜRDAL $\odot$, Bülent OLCAY* \\ Department of Pharmaceutical Botany, Faculty of Pharmacy, Istanbul University, Istanbul, Turkey
}

\begin{abstract}
Article Info
(C2020 Ali Nihat Gökyiğit Botanical

Garden Application and Research

Center of Artvin Coruh University.

*Corresponding author:

e-mail: bulentolcay@istanbul.edu.tr

ORCID: 0000-0002-0521-488X

Article history

Received: April 25, 2020

Received in revised form: May 26, 2020

Accepted: May 31, 2020

Available online: June 24, 2020

\section{(1) (1)}

This is an Open Access article under the CC BY NC ND license (http://creativecommons.org/licenses /by/4.0/).
\end{abstract}

\section{Keywords:}

Medicinal plants, Turkey, conservation, threats, ex situ, in situ

Anahtar Kelimeler:

Tıbbi bitki, Türkiye, koruma, tehditler, ex situ, in situ

\begin{abstract}
Medicinal plants are a special area that needs to be evaluated with different parameters than the general biodiversity threatening due to intense collection pressure.

In the study, Turkey's plant diversity, requirements and strategies for sustainable use of Turkish medicinal plants, criticizing and planning of data for the protection of medicinal plants have been evaluated using standards of the Guidelines on the Conservation of Medicinal Plants by WHO, IUCN, WWF and Traffic. In addition, the richness of traditional medicinal plant uses in Turkey, the concept, and usage potentials, administrative requirements for the protection, creation of the in situ and ex situ conservation areas and recommendations for the future have been presented.
\end{abstract}

\section{öz}

Tıbbi bitkiler yoğun bir toplama baskısı nedeniyle genel biyoçeşitlilik üzerindeki baskıdan daha farklı parametrelerle değerlendirilmesi gereken bir alandır. Çalışmada, Türkiye'nin bitki zenginliği, tıbbi bitki olarak kullanılan bitkilerin sürdürülebilir kullanımı için gereksinimler ve stratejiler, verilerin ve tıbbi bitkilerin korunmasına yönelik planlamalar, WHO, IUCN, WWF ve Traffic tarafından hazırlanmış Tıbbi Bitkileri Koruma Kılavuzu'na göre değerlendirilmiştir. Ayrıca Türkiye'nin geleneksel tıbbi bitki kullanım zenginliği, tıbbi bitki kavramı ve kullanım potansiyeli, korumaya yönelik yönetimsel gereksinimler, in situ ve ex situ koruma alanlarının oluşturulması ve geleceğe yönelik öneriler sunulmuştur.

\section{Citation:}

To cite this article: Akalın E, Gürdal B, Olcay B (2020). General overview on the conservation of medicinal plants in Turkey. Turk J Biod 3(2): 86-94. https://doi.org/10.38059/biodiversity.726745

\section{INTRODUCTION}

Medicinal plants known and used since ancient times are still commonly used, and they have remarkable importance in national and international trade. According to the World Health Organization (1998) data, $80 \%$ of the population of developing countries is used mostly medicinal plants, for their primary health care needs on traditional medicines. Also, modern pharmacopoeias still contain at least $25 \%$ of drugs derived from plants and many others which are synthetic analogues built on prototype compounds isolated from plants (Kingston, 2011). Medicinal plants are used directly as therapeutic agents, but also as starting materials for the synthesis of drugs or as models for pharmacologically active compounds in this respect they have an important role for pharmacological research and drug development (As shown in Table 1). Despite the use of herbal medicines over many centuries, only a relatively small number of plant species have been studied for possible drugs (WHO, 1998). The traditional uses of medicinal plants in the world are documented by ethnobotanical studies. Ethnobotanical/ ethnopharmacological studies are increasing the possibilities of identifying new molecules instead of random screening (Harvey, 1999; De Melo et al., 2011). Plants are threatened in many parts of the world. According to IUCN (2010) data 15,000 species of medicinal plants are globally threatened from, amongst others, loss of habitat, overexploitation, invasive species and pollution (IUCN, 2010; Chen et al. 2016). The United Nations Convention on Biological Diversity states that the conservation and sustainable use of biological diversity is 
of critical importance for meeting the food, health and other needs of the growing world population (WHO, 1998; Heide, 1993). However, the majority of the material traded is still from wild-harvested sources and number of species cultivated are very few. According to the report of WHO, approximately the market (annual) for medicinal and aromatic plants are $\$ 60$ billion in 2000, $\$ 93$ billion in 2015, \$ 107 billion in 2017 in the world (Willis, 2017). Despite lacking detailed information, numerous medicinal plants encounter extinction or endangered. There is no serious conservation action plan for most medicinal plants which are endangered. For instance, there is very little material of them in gene banks. Much importance has been put on the potential for discovering new drugs, less on different problems in use of traditional herbal medicines by indigenous people. There is still no complete inventory of medicinal plants for most countries. Most of the knowledge on their uses are held by traditional societies, whose existence is under threat now. Less data has been recorded by way of systematic approach. Besides the identification and selection of medicinal plants for use in health services, there is the potential that plants hold as an inexhaustible reservoir for the identification and isolation of useful chemical compounds for diseases such as cancer (Akerele et al., 1991; Kathe, 2006).

Table 1. Some examples of raw materials used as herbal medicine or medicine (Benzie \& Wachtel-Galor, 2011).

\begin{tabular}{|c|c|c|c|}
\hline $\begin{array}{l}\text { Isolating pure active compounds } \\
\text { for formulation into drugs }\end{array}$ & $\begin{array}{l}\text { Isolating intermediates for } \\
\text { the production of semi- } \\
\text { synthetic drugs }\end{array}$ & $\begin{array}{l}\text { Preparing standardized } \\
\text { galenicals } \\
\text { tinctures, etc.) }\end{array}$ & Herbal teas \\
\hline Astragalus species (Cycloartanes) & $\begin{array}{l}\text { Ruscus aculeatus (Steroidal } \\
\text { saponins) }\end{array}$ & $\begin{array}{l}\text { Glycyrrhiza glabra (Root } \\
\text { extract) }\end{array}$ & Matricaria chamomilla \\
\hline $\begin{array}{l}\text { Liquidambar orientalis (Cinnamic } \\
\text { acid and deriveties) }\end{array}$ & $\begin{array}{l}\text { Pinus brutia (Resin and } \\
\text { essential oils) }\end{array}$ & $\begin{array}{l}\text { Vitex agnus-castus (fruit } \\
\text { extract) }\end{array}$ & Salvia fruticosa \\
\hline $\begin{array}{l}\text { Leucojum /Galanthus species } \\
\text { (Galanthamine) }\end{array}$ & $\begin{array}{l}\text { Papaver } \quad \text { somniferum } \\
\text { (Opioids) }\end{array}$ & $\begin{array}{l}\text { Colchicum species (Seed } \\
\text { extract) }\end{array}$ & Origanum species \\
\hline Gypsophila species (Saponins) & $\begin{array}{l}\text { Colchicum } \\
\text { (Colchicosides) }\end{array}$ & $\begin{array}{l}\text { Sambucus nigra (Flower } \\
\text { extract) }\end{array}$ & $\begin{array}{l}\text { Sideritis species ( } S \text {. congesta, } S \text {. } \\
\text { caesarea, S. stricta) }\end{array}$ \\
\hline $\begin{array}{l}\text { Mentha spicata, M. pulegium } \\
\text { (Menthol) }\end{array}$ & & $\begin{array}{l}\text { Hypericum } \\
\text { (Herb extract) }\end{array}$ & Melissa officinalis \\
\hline $\begin{array}{l}\text { Papaver somniferum (Morphine, } \\
\text { thebaine, codeine, papaverine } \\
\text { etc.) }\end{array}$ & & $\begin{array}{l}\text { Crataegus monogyna (Leaf, } \\
\text { flower, fruit extract) }\end{array}$ & Tilia sp. \\
\hline \multirow[t]{2}{*}{ Artemisia absinthium (Absinthe) } & & Viscum album (Leaf extract) & Althaea officinalis \\
\hline & & $\begin{array}{l}\text { Scolymus hispanicus (Leaf } \\
\text { and flower extract) }\end{array}$ & \\
\hline
\end{tabular}

\subsection{Medicinal plants in Turkey}

Turkey has a rich flora with approximately 12,000 taxa of vascular plants - one- third of them endemic to the country (Davis, 1965-1985; Davis et al., 1988; Güner et al., 2000; Özhatay et al., 2015, 2017). Traditional knowledge of medicinal plants is common and it is transferred inter-generational. According to ethnobotanical studies 1546 species are recorded as medicinal plants in Turkey (Tuzlacı, 2016). In Turkey, the number of plants collected from nature which is subject to trade in the domestic market is about 350 . Approximately 100 of these plants are exported. In Turkey, agriculture of 20 kinds of medicinal and aromatic 
plants is done in 1.3 million acres although it has changed over the years. Black tea, red pepper, poppy, cumin, mint, oregano, rose oil and anise are placed near the top in terms of production amount. (TTOD, 2018) (As shown in Table 2). Legalizations in Turkey related to medicinal plants are given below. Medicinal plants have to be licensed if they are to be sold as a herbal medicinal product except for traditional uses. The critical part here is whether the indication is specified. Accordingly, two licenses are issued by authorities in Turkey. The products licensed from the Ministry of Agriculture usually come out as nutritional supplements. Indication is not included: Ministry of Agriculture and Forestry authorization;

It contains indications: Ministry of Health authorization, Traditional Herbal Medicinal Products Directive, Ministry of Health authorization- October 6, 2010, Supplemental Imports of Food, Production, Processing and Marketing Regulations, Ministry of Food, Agriculture and Livestock authorization- May 2, 2013.

Table 2. Medicinal and aromatic plants cultivation area and production status over the years in Turkey (TUIK 2020).

\begin{tabular}{|c|c|c|c|c|c|c|c|c|c|}
\hline \multirow[b]{2}{*}{ No } & \multirow[b]{2}{*}{ Plant name } & \multicolumn{2}{|c|}{2006} & \multicolumn{2}{|c|}{2012} & \multicolumn{2}{|c|}{2015} & \multicolumn{2}{|c|}{ Change \% } \\
\hline & & Hectares & Tons & Hectares & Tons & Hectares & Tons & Hectares & Tons \\
\hline 1 & Black tea & 76.613 & 112.120 & 75.856 & 125.000 & 76.207 & 132.793 & -0.1 & 7.5 \\
\hline 2 & Red pepper & 6.696 & 4.586 & 11.268 & 16.553 & 11.289 & 20.413 & 3.9 & 85.7 \\
\hline 3 & Poppy & 42.024 & 2.744 & 13.510 & 350 & 61.591 & 3.073 & 12.4 & 16.6 \\
\hline 4 & Cumin & 21.154 & 1.199 & 22.629 & 1.390 & 27.024 & 1.690 & 10 & 14.5 \\
\hline 5 & Mint & 989,4 & 959 & 1.047 & 1.260 & 1.058 & 1.494 & 5.2 & 19.9 \\
\hline 6 & Thyme & $5.885,3$ & 798 & 9.428 & 1.160 & 10.486 & 1.300 & 10 & 8.6 \\
\hline 7 & Rose (for oil) & $1.700 *$ & $840^{*}$ & 3.083 & 1.022 & 2.824 & 948 & 6.3 & 4.4 \\
\hline 8 & Anise & $12.654,2$ & 8478 & 19.443 & 1.102 & 13.812 & 905 & -6.2 & -5.5 \\
\hline 9 & Dill Grass & 260 & 245 & 326 & 290 & 478 & 449 & 17 & 16.4 \\
\hline 10 & Heather & - & - & - & - & 1.503 & 208 & - & - \\
\hline 11 & Hops & 267,7 & 138 & 344 & 175 & 350 & 187 & 1 & 15.3 \\
\hline 12 & Fennel & - & - & 1.577 & 186 & 1.551 & 146 & -0.2 & 136.1 \\
\hline 13 & Black cumin & - & - & 230 & 16 & 468 & 42.5 & 10.4 & 32.5 \\
\hline 14 & White Lupin & 601 & 48 & 468 & 42 & 374 & 41 & -1.7 & 1.5 \\
\hline 15 & Lavender & - & - & 51 & 12 & 329 & 40 & 53 & 22.5 \\
\hline 16 & Lemon balm & - & - & 45 & 24 & 51 & 24 & 1.4 & 0.2 \\
\hline 17 & Sage & - & - & 5.4 & 0.7 & 53.6 & 1.9 & 89.3 & 17.1 \\
\hline 18 & Coriander & - & - & 1.1 & 0.1 & 15 & 1.1 & 126.4 & 100 \\
\hline 19 & Caper bush & - & - & - & - & 1.5 & - & - & - \\
\hline 20 & Stinging nettle & - & - & 0.3 & 0,042 & 0 & 0 & - & - \\
\hline 21 & Linen & 144,8 & 8.4 & 18 & 1.3 & 0 & 0 & -10 & -10 \\
\hline \multirow[t]{2}{*}{22} & Hemp & 65 & & 6.4 & & 1 & 0.1 & -10 & -10 \\
\hline & Total & 167.355 & & 159.338 & & 209.461 & & 2.2 & \\
\hline
\end{tabular}




\subsection{Conservation strategies}

Conservation is very important to benefit from the medicinal plants and also for sustainability. The aim of conservation is to support sustainable uses and protecting biological resources. Two methods for the conservation of plant genetic resources are valued, namely in situ and ex situ conservation. Some approaches for ex situ conservation include gene banks, seed storage, pollen storage, botanical gardens. (Kasagana \& Karumuri, 2011). Turkey Seed Gene Bank in business under Biodiversity and Genetic Resources Department of Field Crops Central Research Institute was inaugurated in 2010. 122.000 materials are conserved in the Seed Gene Banks as of 2015. Ex situ conservation of some threatened species is conducted at the Nezahat Gökyiğit Botanic
Garden, Istanbul. Botanical gardens in Turkey are shown in Table 3. In situ conservation involves establishing protected areas and taking an approach that is habitat/ecosystem-oriented (Chen et al., 2016). Total 144 of sites are identified as an IPA (Important Plant Area) in Turkey (Özhatay et al., 2010, Özhatay, 2006). In addition to this, small protected areas and hot spots are identified in Turkey (Akalın et al., 2013; Kocyigit \& Demirci, 2018). Species Action Plan Projects have been carried out by the Republic of Turkey Ministry of Agriculture and Forestry. Different strategies have been developed for plant conservation. The situation of medicinal plants in Turkey was evaluated using the standards of the Guidelines on the Conservation of Medicinal Plants published by WHO, IUCN, WWF and TRAFFIC (Akerele et al., 1991, Kathe, 2006).

Table 3. Botanical gardens in Turkey (Ekim, 2017).

\begin{tabular}{|c|c|c|c|c|}
\hline Botanical Garden & $\begin{array}{l}\text { Establish } \\
\text { date }\end{array}$ & $\begin{array}{l}\text { Herbarium } \\
\text { specimens }\end{array}$ & Number of taxa & Medicinal plant department \\
\hline $\begin{array}{l}\text { Alfred Heilbronn Botanic Garden } \\
\text { (İstanbul) }\end{array}$ & 1935 & $\begin{array}{l}50000 \\
\text { samples }\end{array}$ & 6000 & None \\
\hline $\begin{array}{l}\text { Atatürk Arboretum of İstanbul } \\
\text { University (İstanbul) }\end{array}$ & 1949 & $\begin{array}{l}40000 \\
\text { samples }\end{array}$ & 1650 & None \\
\hline $\begin{array}{l}\text { Ege University Botanical Garden } \\
\text { (İzmir) }\end{array}$ & 1968 & $\begin{array}{l}30000 \\
\text { samples }\end{array}$ & 3000 & None \\
\hline $\begin{array}{l}\text { Çukurova University Ali Nihat } \\
\text { Gökyiğit Botanic Garden (Adana) }\end{array}$ & 1999 & $\begin{array}{l}250 \\
\text { samples }\end{array}$ & 600 & Yes 180 taxa \\
\hline Karaca Arboretum (İstanbul) & 1980 & $\begin{array}{l}\text { Non } \\
\text { herbarium }\end{array}$ & $\begin{array}{l}\text { Woody plants (c. } 7000 \\
\text { taxa) and herbaceous } \\
\text { perennials (c. } 7000 \text { taxa) }\end{array}$ & None \\
\hline $\begin{array}{l}\text { Nezahat Gökyiğit Botanic Garden } \\
\text { (İstanbul) }\end{array}$ & 2001 & $\begin{array}{l}8500 \\
\text { samples }\end{array}$ & $\begin{array}{l}\text { Woody plants (c. } 800 \\
\text { taxa) and herbaceous } \\
\text { perennials (c. } 6000 \text { taxa) }\end{array}$ & $\begin{array}{l}\text { Medicinal and aromatic } \\
\text { plants in the useful plants } \\
\text { department } 115 \text { taxa }\end{array}$ \\
\hline $\begin{array}{l}\text { Zeytinburnu Medicinal Plants } \\
\text { Garden (İstanbul) }\end{array}$ & 2005 & $\begin{array}{l}300 \text { taxa, } \\
100 \text { seed }\end{array}$ & 800 & First medicinal plants garden \\
\hline
\end{tabular}

\section{MATERIAL AND METHODS}

The goal of the study defines the outlines of Turkey's threats and protection management on medicinal plants used as natural resources. For this purpose, the criteria of
The Guidelines on the Conservation of Medicinal Plants (Kathe, 2006) are followed for the evaluation of Turkish medicinal plants. The data were obtained as a result of the literature research and evaluated. 


\section{RESULTS AND DISCUSSIONS}

The guideline states that due diligence must be made about medicinal plants, management's approach and solutions must be evaluated. In this study, this process will be followed. There are also suggestions in the last section. The attitude of the central government is the most important part of the protection of Medicinal Plants like all good management processes.

\subsection{To study traditional knowledge on the use of plants in health care}

Many academic or folkloric studies are carried out about the usage of plants mainly for medicinal purposes in Turkey. Studies on "Determination of Traditional Knowledge Based on Biological Diversity" started in 20172018 are carried out under the coordination of the Republic of Turkey Ministry of Agriculture and Forestry, General Directorate of Nature Conservation and National Parks, Department of Biological Diversity. In these surveys, it is mainly aimed to investigate medicinal plants. Up to this day, inventory studies for 11 provinces in two parts have been planned and started, but some of them have not been yet concluded. These provinces are Ankara, Hatay, Erzurum, Afyon, Çorum, Aydın, Samsun in first part and Mersin, Bursa, Şanlıurfa, Gümüşhane in second part. The Project of Recording Traditional Information Based on Biodiversity is carried out by Ministry of Agriculture and Forestry, General Directorate of Nature Conservation and National Parks. In the first group, the Project were ended in Aydın, Afyonkarahisar, Hatay, Ankara, Erzurum, Samsun and Çorum provinces in 2018. In the second group, field work in Bursa, Mersin, Kayseri, Gümüşhane and Şanlıurfa provinces was completed in 2019. Project studies are continuing in Kırklareli, Mardin, İzmir, Isparta, Aksaray, Sinop, Bartın, Trabzon and Van, which started in 2019. It is aimed to complete field work in all provinces by 2023 (UBSEP, 2013). Also, Ministry of Health issued a regulation in order to make an arrangement associated with traditional treatment methods (GETAT, 2014).

\subsection{To identify the medicinal plants, outline their distributions and assess their abundance}

Turkey that the plant diversity is the richest country is located in the temperate zone. 12000 vascular plant taxa grow naturally in Turkey. Approximately $35 \%$ of these plants are endemic. Each year, an average of 60 new species is added to the Flora of Turkey (Özhatay et al., 2017). Taxonomic and floristic studies have contributed greatly in recent years. There is not a national herbarium in Turkey yet. However, especially in faculties of pharmacy herbaria are located and have rich collection of medicinal plants. For example, Istanbul University The Herbarium of the Faculty of Pharmacy (ISTE) with 130000 samples has nearly all species of important medicinal genera (Papaver, Salvia, Allium, Rosa, Ferula etc.) and all important medicinal species. In some herbaria, such as IZEF or ISTE, the databases for medicinal plants have been made for documentation. These databases will be a considerable important step in the systematical determination and protection of traditional medicinal plants. Currently, there are two special databases for the traditional use of plants:

Data Bank of Turkish Folk Remedies (TUHIB-Türk Halk ilaçları Bilgi Bankası); According to this database, the number of species used as folk remedy in Turkey have recently been figured around 1,500 (Yesilada, 2002). Turkish Ethnobotanical Data Bank (TEBVET Türk Etnobotanik Veri Tabanı); It is reported that approximately 1,200 species used for medicinal purposes (Ospankulova, 2005). These data are cataloged and analyzed in some papers. But there is no regulation about making benefits to the communities providing the data from any commercial use of the information. The most vital point is to determine correctly named plant.

\subsection{Wherever possible, to cultivate the medicinal plants as the source of supply}

Only 130-140 species are cultivated in Europe. This number is being 20 species in India, 100-250 species in China (Canuto et al., 2012). The majority of medicinal and aromatic plants in Turkey (347 species) are collected from nature and directly consumed or sold in the domestic market. Some of them are Glycyrrhiza glabra (licorice), Rosmarinus officinalis (Rosemary), Salvia sp. (Sage types), Sideritis sp. (Ironwood worth), Origanum sp. (Marjoram), Satureja sp. (Savory), Capparis sp. (Kebere), Gypsophilla sp. (Soapwort) and some bulbous plants such as Galanthus sp. (Snowdrop) and Orchis sp. (Orchid) (Özhatay et al., 1997; Sandal \& Söğüt, 2010). Some of the projects for cultivation of medicinal plants have been undertaken, but there is no permanent plan in Ministry of Agriculture and Forestry or Ministry of Health. Horticultural Research Institutes improve the agronomy of cultivated medicinal plants and bring into cultivation those species needed in medicine that have not been cultivated before and provide effective horticultural training and information. Such as Atatürk Horticultural 
Central Research Institute, Ege Horticultural Central Research Institute, Zeytinburnu Medicinal Plant Botanic Gardens.

\subsection{To ensure that any collecting from the wild is sustainable}

There is no regulation on the collection of medicinal plants (except geophytes) from the wild or no control on trade in medicinal plants and their products. Solution suggestions in this area can be planned in two parts;

Primarily, organizing collections under control from nature, and training about sustainable collecting by official authorities and increased the awareness of local people who collect the medicinal plants.

The second and more sustainable way, instead of collecting from nature, these plants can be cultivated in accordance with ecological and social interests. From an ecological ethnobotanical point of view, an economic system should be created based on community interactions and human behavior- conservation, genetic preservation.

\subsection{To improve techniques for harvesting, storage and production}

Medicinal plants have special importance for Turkey. Cultivation, harvesting, production and trading of these plants should be organized by a single authority, although it is under the jurisdiction of different ministries such as agriculture, forestry or health. Ministry of Agriculture and Forestry improves the techniques for harvesting and storing medicinal plants and preparing products by Horticultural Research Institutes. Herbal monographs of important medicinal plants for Turkey are preparing to take part in the Turkish Pharmacopoeia by the Ministry of Health. For example: Silivri Municipality Agricultural Production and Research Center (TÜRAM) is founded in Silivri in 2009 and started the trial process in 2010 in cooperation with Namık Kemal University Faculty of Agriculture. Agricultural production and research centers, which will be established with such cooperation, will prevent the collection of plants used for medicinal purposes from nature and will prevent the damage to biological diversity.

\subsection{To conserve populations of medicinal plant species in natural habitats}

In Turkey, the most areas belong to a Protected Area System and are governed by national laws. The list of protected areas is within the protected area system in Turkey (2013) (As shown in Table 4). However, these areas including medicinal plants are not considered when determining a protected area system.

Table 4. Summary of Protected Areas in Turkey (DKMP, 2018).

\begin{tabular}{|l|l|l|}
\hline \multicolumn{3}{|c|}{ Protected Areas in Turkey } \\
\hline National Park & National & 44 \\
\hline Nature Conservation Areas & National & 30 \\
\hline Nature Park & National & 243 \\
\hline Natural Monument & National & 112 \\
\hline Wildlife Protection Areas & National & 81 \\
\hline Protective Forests & National & 58 \\
\hline Natural Sites & National & 1273 \\
\hline Special Protected Areas & Regional & 16 \\
\hline Ramsar Sites & Global & 14 \\
\hline Biosphere Reserve Areas & Global & 1 \\
\hline World Heritage Areas & Global & 11 \\
\hline
\end{tabular}

\subsection{To conserve populations of medicinal plant species ex situ}

Valuable tools are both in situ and ex situ conservation for medicinal plant conservation. Related to these tools, inventorying and monitoring of medicinal plant species and their populations, medicinal-plant resource management and the role of gene banks and tissue cultures are important. Species Action Plan Projects were targeted for 100 endangered species (plants and animals) between 2013-2019 years. The action plan of 60 species had been completed in 2017. While there was a conservation action plan for many rare and threatened species, an action plan was made by the fight against invasive species, such as Sicyos angulatus (itdolanbacı) in Giresun. At the end of 2019, 20 more action plans were planned (As shown in Table 5). There are particularly rare and endemic species in these plans, although they are not species that are collected for direct medical purposes, they are found in some species of medicinal genera with numerous species, such as Astragalus, Ferula, Hypericum, Salvia and Verbascum. There are no species collected from nature for commercial purposes. 
Table 5. Some plant species that their protection action plans have been completed or ongoing (UBENIS, 2013).

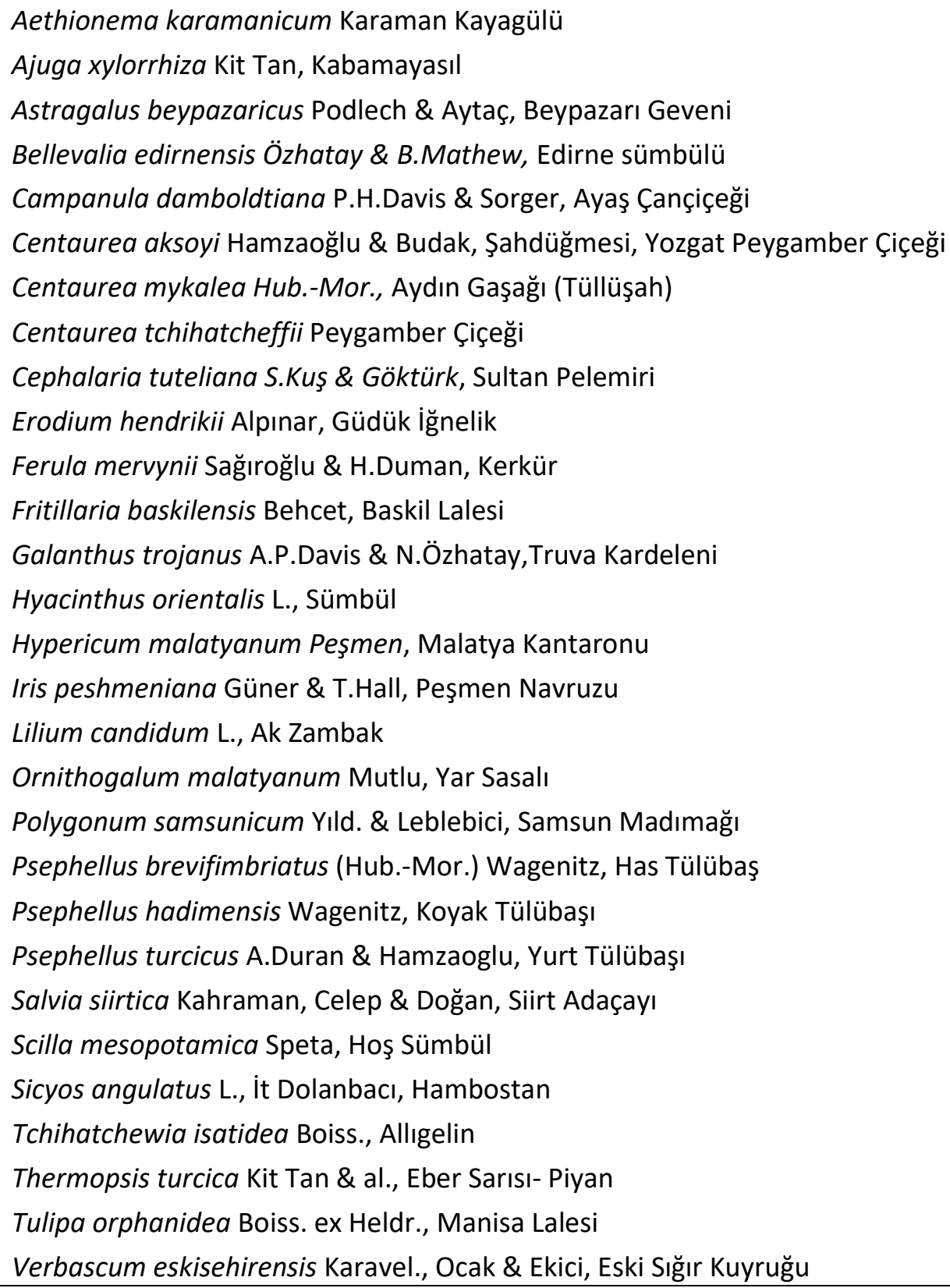

3.8. To build public support for the conservation of medicinal plants through communication and cooperation

Conservation of wild medicinal plants requires conservation of their habitats and thus success in conserving medicinal plants (driven by the motivational forces of health, income or culture) and it has the potential to benefit many other types of plants and animals too. Several types of conservation measures have been applied to medicinal plants, including protected areas and other forms of legal control, cultivation (intended to reduce the collection pressure on wild medicinal plants) and ex situ conservation. Protected areas are useful for conserving medicinal plants - as important for biodiversity in general. Theoretically, welldesigned networks of protected areas would be great value for conserving the genetic diversity of medicinal species, though in actuality it is doubtful whether the geography of medicinal plants has ever been a serious consideration in designing such networks. The 
identification of IMPAs (Important Medicinal Plants Area) is based on four broad criteria (Akalın \& Özhatay, 2014):

- Medicinal plants in the site: Ethnobotanical data or regional anthropological research.

-Threatened species in the medicinal plants: Endemic and rare plants, especially only grew up a certain habitat, slowly growing or extensive collecting (e.g. Gentiana lutea)

- Threatened habitats: The last 40 years, rare habitats are threatened in Turkey (mining, deforestation or reforestation, to achieve land, water policy, etc.)

-Rich genera or families where have important medicinal plants: such as Papaver, Salvia genera or Apocynaceae, Apiaceae or Labiatae families.

Nowadays, clearly visible and measurable threats on biodiversity, which are very important in terms of our future, have given a great impetus to the protection studies of these areas. Medicinal plants are also one of the most important subjects of such studies. It is possible that these plants may be more threatened than the others in Anatolia or the world. 144 Important Plant Areas (IPA) of Turkey are determined (Özhatay et al., 2010; Özhatay, 2006). The Republic of Turkey Ministry of Agriculture and Forestry start the projects of Recording Traditional Knowledge Based on Biodiversity in 2017. Several protected areas (National parks, biosphere reserve areas etc.) have been identified in Turkey. When utilized all of these, the criteria of important medicinal plant areas can be carried out in these areas (Akalın \& Özhatay, 2014). Then focusing on ex situ/ in situ conservation or cultivation of endangered medicinal plants of Turkey is important for sustainability. In Turkey, 1500 different plants for different purposes have been used (Yesilada, 2002).

\section{Acknowledgements}

This study was started with suggestion of Prof. Dr. Neriman ÖZHATAY who studies to determine the plant diversity and conservation areas in Turkey, we gratefully thanks.

\section{REFERENCES}

Akalın E, Özhatay FN, Güler N, Ersoy H, Başak N, Yeşil Y, Oral D, Demirci $S$ (2013). The flora of Yıldız Mountains (Kırklareli) Biosphere Project area. Turkish Journal of Botany 37(2): 225-269. DOI:10.3906/bot1111-5.
Akalın E, Ozhatay N (2014). Important Medicinal Plant Areas for Turkey: Kaz Dağı IMPA. XXI. Bitkisel ilaç Hammaddeleri Toplantısı (XXI. BIHAT), 28 May-1 June 2014; Kayseri, Turkey, DK.3.

Akerele O, Heywood V and Synge H (eds) (1991). Conservation of medicinal plants, Cambridge: Cambridge University Press, 362p.

Benzie IF, Wachtel-Galor S (eds) (2011). Herbal medicine: biomolecular and clinical aspects. Los Angeles: CRC press, 500p.

Canuto KM, Silveira ER, Bezerra AME, Leal LKAM and Viana GSB (2012) Phytochemistry, Pharmacology and Agronomy of Medicinal Plants: Amburana cearensis, an Interdisciplinary Study in Rao V (ed.) Phytochemicals - A Global Perspective of Their Role in Nutrition and Health, InTech Publishing, Rijeka, Croatia, 358p.

Chen SL, Yu H, Luo HM, Wu Q, Li CF, Steinmetz A (2016). Conservation and sustainable use of medicinal plants: Problems, progress, and prospects. Chinese Medicine (United Kingdom) 11(1): 1-10. DOI:10.1186/s13020-016-0108-7.

Davis PH, (ed) (1965-1985). Flora of Turkey and the East Aegean Islands Vol. 1-9. Edinburgh: Edinburgh University Press.

Davis PH, Mill RR, Tan, K (eds) (1988). Flora of Turkey and the East Aegean Islands (supplement 1), vol. 10. Edinburgh: Edinburgh University Press, 590p.

De Melo JG, Santos AG, De Amorim ELC, Nascimento SCDo, De Albuquerque UP (2011). Medicinal plants used as antitumor agents in Brazil: An ethnobotanical approach. Evidence-Based Complementary and Alternative Medicine 2011: 1-14. DOI: $10.1155 / 2011 / 365359$.

DKMP (2018). Doğa Koruma ve Milli Parklar Genel Müdürlüğü. https://www.tarimorman.gov.tr/DKMP/Menu/18/Korunan-AlanIstatistikleri. Published on the internet. Downloaded on 26 May 2020.

Ekim T (2017). Botanik bahçeleri ve önemi. Z Kültür,Sanat,Şehir Mevsimlik Tematik Dergi Yaz 2017/1 Bitki Ressamlığı 2017(1): 124143.

GETAT (2014). Geleneksel ve tamamlayıcı tıp uygulamaları yönetmeliği. https://www.resmigazete.gov.tr/eskiler/2014/10/201410273.htm. Published on the internet. Downloaded on 26 May 2020.

Güner A, Özhatay N, Ekim T, Başer KHC (eds) (2000). Flora of Turkey and the East Aegean Islands (supplement), Edinburgh: Edinburgh University Press, 656p.

Harvey AL (1999). Medicines from nature: are natural products still relevant to drug discovery?. Trends in Pharmacological Sciences 20(5): 196-198.

Heide L (1993) Traditionelle Arzneipflanzen in der Gesundheitsversorgung der dritten Welt-Möglichkeiten und Grenzen. Deutsche Apotheker Zeitung-Stuttgart 133: 17-17.

IUCN (2010). New prescription needed for medicinal plants. https://www.iucn.org/content/new-prescription-neededmedicinal-plants. Downloaded on 18 May 2010.

Kasagana VN, Karumuri SS (2011). Conservation of medicinal plants (past, present \& future trends). Journal of Pharmaceutical Sciences and Research 3(8): 1378-1386.

Kathe W (2006). Revision of the 'Guidelines on the Conservation of Medicinal Plants' By WHO, IUCN, WWF and Traffic. Medicinal and Aromatic Plants 109-120. DOI:10.1007/1-4020-5449-1_8.

Kingston DGI (2011). Modern natural products drug discovery and its relevance to biodiversity conservation. Journal of natural products, 74(3): 496-511. DOI: 10.1021/np100550t.

Kocyigit M, Demirci KS (2018). "Small Protected Areas" for Conservation Priorities in South Anatolia (Başkonuş Mountain- 
Kahramanmaraş). European Journal of Biology 77(2): 89-96. DOI:10.26650/eurjbiol.2018.0013.

Ospankulova E (2005). Türkiye'nin etnobotanik veri tabanı. MSc, Istanbul University, Istanbul, Turkey.

Özhatay N, Koyuncu M, Atay S, Byfield A (1997). The Wild Medicinal Plant Trade in Turkey. Istanbul: The Society for the Protection of Nature (DHKD). 222p.

Özhatay N (2006). Important plant areas along BTC pipeline in Turkey. Istanbul: BTC Sirketi, 304p.

Özhatay N, Byfield A, Atay S (eds) (2010). Important plant areas in Turkey: 122 Key Turkish botanical sites. Istanbul: WWF Turkey, $476 p$.

Özhatay N, Kültür Ş, Gürdal B (2015). Check-list of additional taxa to the supplement flora of Turkey VII. Istanbul Journal of Pharmacy 45(1): 61-86.

Özhatay N, Kültür Ş, Gürdal B (2017). Check-list of additional taxa to the supplement flora of Turkey VIII. Istanbul Journal of Pharmacy 47(1): 31-46.DOI:10.5152/IstanbulJPharm.2017.006.

Sandal G, Söğüt Z (2010). Orchids of Turkey (Salep), Akdeniz Üniversitesi Ziraat Fakültesi Dergisi 23(2): 109-116.

TTOD (2018). Türk Tarım Orman Dergisi. Published on the internet. http://www.turktarim.gov.tr/Haber/64/turkiye-tibbi-ve- aromatik-bitki-yetistiriciliginde-oncu-ulkelerden). Downloaded on 11 April 2020.

Tuzlacı E (2016). Türkiye Bitkileri Geleneksel İlaç Rehberi. İstanbul: istanbul Tıp Kitabevleri, 1460p.

TÜiK (2020). Türkiye İstatistik Kurumu. Published on the internet. http://www.tuik.gov.tr. Downloaded on 29 March 2020.

UBENIS (2013). Ulusal biyolojik çeşitlilik envanter ve izleme projesi. http://www.nuhungemisi.gov.tr/Projects/Ubenis. Published on the internet. Downloaded on 26 May 2020.

UBSEP (2013). Nuh'un gemisi ulusal biyoçeşitlilik veri tabanı. http://www.nuhungemisi.gov.tr/. Published on the internet. Downloaded on 26 May 2020.

WHO (1998). Regulatory situation of herbal medicines: a worldwide review (No. WHO/TRM/98.1). Geneva: Switzerland, 45p.

Willis KJ (2017). Useful plants - medicines. State of the World's Plants 2017: 100. DOI:978-1-84246-628-5.

Yesilada E (2002). Biodiversity in Turkish Folk Medicine. In: Şener B. (ed). Biodiversity: Biomolecular Aspects of Biodiversity and Innovative Utilization. London: Kluwer Academic/Plenum Publishers, pp. 119- 135. 